\title{
Scrotal Lipoma: A Case Report
}

\section{Skrotal Lipom: Bir Olgu Sunumu}

\author{
Mustafa Kara ${ }^{1}$, Fatin Rüştü Polat ${ }^{2}$, Ali Burak Göçer ${ }^{1}$ \\ 1 Yenikent Devlet Hastanesi, Radyoloji Kliniği, Sakarya, Türkiye \\ ${ }^{2}$ Toyota Devlet Hastanesi, Genel Cerrahi Kliniği, Sakarya, Türkiye
}

\begin{abstract}
Benign mesenchymal tumors of the scrotum are rare. 60-year-old patient, was admitted to our department with palpable mass in scrotum. Magnetic Resonance Imaging and Ultrasonography findings of scrotal mass was diagnosed as lipoma. In this paper, we report imaging findings of the intrascrotal lipoma and review of the literature.
\end{abstract}

Keywords: Scrotum, Lipom, Magnetic Resonance Imaging, Ultrasonography

Başvuru Tarihi: 20.02.2011 Kabul Tarihi: 16.03.2011

\section{Özet}

Skrotal benign mezenkimal tümörler nadirdir. 60 yaşında olan olgumuz, skrotumda ele gelen kitle ile bölümümüze başvurdu. Manyetik Rezonans Görüntüleme ve ultrasonografi bulguları ile skrotal lipom tanısı konuldu. Olgunun görüntüleme bulgularını ve konu ile ilgili literatürün gözden geçirilmesini sunuyoruz.

Anahtar Kelimeler: Skrotum, Lipom, Manyetik Rezonans Görüntüleme, Ultrasonografi

Aplication: 20.02.2011 Accepted: 16.03.2011

\section{Giriş}

Bening mesencymal tumors of the scrotum are rare. Although they usually originate from epididiymis or spermatic cord, they also may originate from the tunica vaginalis. A Case of lipoma that arise from the tunica vaginalis and is manifested as a painless scrotal mass have been reported. ${ }^{1}$ In this case, a scrotal lipoma image is presented with diagnostic findings because of its rare condition.

\section{Case Report}

A 60 years old male was applied for our deparment because of scrotal mass. On the examination of the scrotum a mass was identifed infero-lateral on the left testicle. He was examined with Ultrasonography (US) and Magnetic Resonance Imaging (MRI).
The US examination revealed a hypoecoic, welldefined, solid and inhomomogeneus mass on inferolateral on the left testicle (Figure 1). MRI demonstrated a mass in the scrotum which was on infero-lateral on the left testicle and which seemed hyperintense on T1-weight (T1W) image (Figure 2) and which seemed hypointense on fat-suppressed T1W image (Figure 3).

\section{Figure 1:}
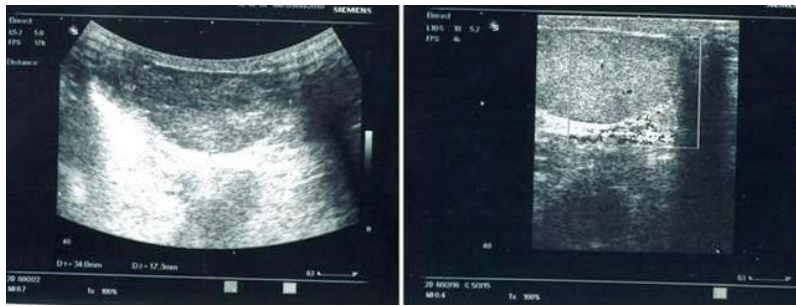
US and MRI show diagnostic findings of scrotal lipoma.

Figure 2:

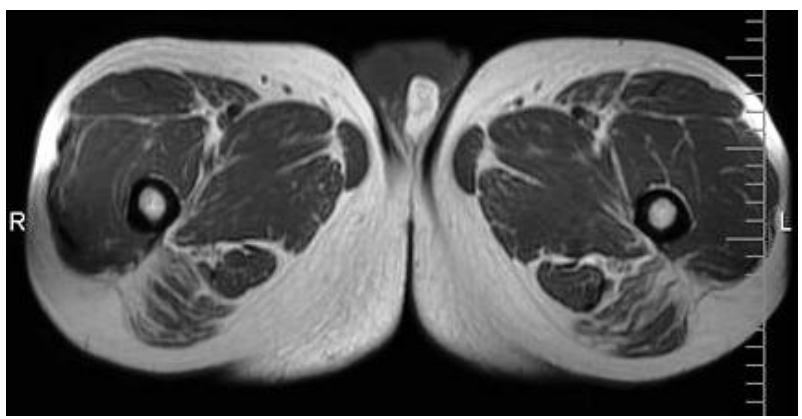

Figure 3:

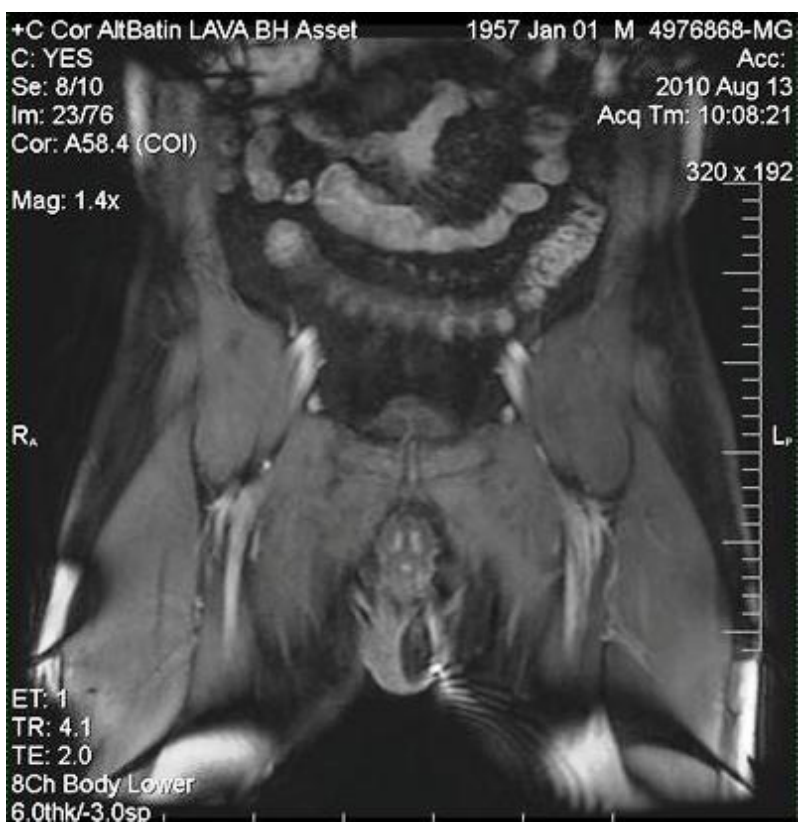

Scrotal lipom is a rare condition, only five cases reported in the literature. They are characterized by being well circumscribed and having no malign potential. Although the natural history of lipoma has not been completly elucidated, there have been no reports of malignant change. $^{2}$

At US, lipomas tend to be well-defined, homogeneus, and hiperechoic, however, a hypoechoic or heterogeneous echotexture may be seen in the presence fibrous, myxoid, or vasculer tissue. ${ }^{3}$ US image shows heterogeneous echotexture in the case (Figure 1).

Lipomas also may arise within the spermatic cord. They demonstrate high signal intensity on T1W images and the signal intensity of other adipose tissue on T2- weighted images. ${ }^{4}$ As with other fatty lesion, loss of signal intensity on fat-suppressed images is a diagnostic finding. ${ }^{1}$ The same sign was seen in our case (Figure 2-3).

Most extratesticular lesions originate from or depend on the tunica vaginalis, a mesothelium-lined sac with a visceral layer and a parietal layer. The tunica vaginalis also may be affected by inflammatory and traumatic disorders such as scrotal calculi, fibrous pseudotumor, or hematocele. These lesions manifest as solid or heterogeneous tumorlike masses. Entrapped mesenchymal cells can lead to lipoma, leiomyoma, or sarcoma, although these tumors are uncommon in the tunica vaginalis. ${ }^{1}$ The exact explanation for the production of scrotal lipom is unclear, although several theories have been proposed, including anomalous appropriation of cells, initial longitudinal duplication of the genital ridge and transverse division of the genital ridge, either through some local accident of development of peritoneal bands. ${ }^{5}$

Scrotal lipomas are rare. Findings of US and especially MRI are diagnostic for scrotal lipomas.

\section{References}

1. Garriga V, Serrano A, Marin A, Medrano S, Roson N, Pruna X. US of the tunica vaginalis testis: anatomic relationships and pathologic conditions.Radiographics 2009;29:2017-2032.

2. Dy JS, Fuchs A, Palmer LS. Benign intrascrotal lipoblastoma in a child. Urology 2007;70:372.

3. Woodward PJ, SchwabCM, Sesterhenn IA. Extratesticular scrotal masses: radiologic-pathologic correlation. RadioGraphics 2003; 23:215-240.

4. Noone CT, Semelka R, Firat Z and Kubik-Huch R. Male Pelvis. In: Semelka R (eds), Abdominal-Pelv Semelka R. Abdominal- Pelvic MRI Second Edition . New Jersey, Jhon Wiley \& Sons;2006: 11791218.

5. Lanza P, Scalfari A, Gemelli R, Pirritano D, Catuogno C, Colosimo MT. Polyorchism: a case report. Arch Esp Urol 1991;44:291-293. 